\title{
Eighteenth Annual Conference of the American Council for the Study of Islamic Societies (ACSIS)
}

The American Council for the study of Islamic Societies (ACSIS) held its 18th Annual Conference April 27-28, 2001 at Villanova University, Pennsylvania. ACSIS was established in 1983 to bring together scholars engaged in the study of Islamic Societies and states around the world from religious, cultural, economic and political perspectives. ACSIS also has a strong focus on Pakistan Studies. The program director, Dr. Hafeez Malik must be congratulated for consistency with which ACSIS continues to meet and produce its publication The Journal of South Asian and Middle Eastern Studies.

In a small symposium with a total of seven panels and some 20 speakers (except the absentees), panel areas covered ranged from Turkey and the West to Muslims in Tibet and China, while the subjects were as diverse as foreign policy, media studies and pluralism.

The first panel began with the discussion of Turkey's role in the European Union (EU). Augusta State University's Michael Bishku's presented "Destination European Union? The Politics and Economics of Turkey's Case for Admission" The paper put the conference to a good start because the following two papers by James Sowerwine and John Vander Lippe dealt with topic directly related to Turkey's admission into European Union. Respectively, these papers were "The Role of Turkey in European Security" and "Turkish-American Relations".

Bishku pointed out at the unevenness and asymmetrical relationship that characterized the Turkey-EU relations. EU's integration itself is not entirely a democratic exercise but a product of European search for enduring security, a quasi-Utopian dream of European integration ideologues and a generation of technocratic elite who want Europe unified. Similarly, the earlier Turkish elite wanted to enter EU for the reasons of changing identity, economic or civilizational, whereas the society at that time was still traditional and felt a deeper bond with the Muslim world than secular Europe. However, the current Turkish drive for membership in EU comes surprisingly not from the secular elite but the very Islamic sectors of society; while the elite wants to hold on to the Kemalist power apparatus, the society wants to democratize and join the EU, because by doing so, the state will no longer be able to pursue its Machiavellian tactics on its citizens, as it would have to abide by, in substance, to the Human Rights 
Charter, Freedom of Speech \& Religion, and other ideals of liberalism that it claims adherence to.

In the same vein, Sowerwine's discussion of The Role of Turkey in EU's security, reinforced the same paradox. Turkey's utility as a partner in regional security is crucial for the Europeans. The Europeans like to see Turkey in NATO alliance, given its proximity to the Middle East. Turkish state's accommodation of Israel is equally comforting to the European policy makers. The State-Society hiatus informs most of discussions of the internal matters of Turkey and its relationship with EU is not based on any concrete set of principles, ideology or common civilizational ideas but merely a relationship of convenience.

The next panel "China, Tibet and Central Asia" was equally interesting. Yi Sun of University of San Diego gave an interesting account of the Chinese Muslims of Sinkiang-Uigur region and their uneasy coexistence with the Chinese state. China's Turkistan (West China) which borders with Pakistan is home to numerous Muslims who often clash with the Chinese state because of religion. This presentation was followed by another presentation and a half-hour documentary on the Muslims of Tibet. Gray Henry of Fons Vitae and the Islamic Text Society presented a visual ethnographic account of a second generation Tibetan Muslim who goes back to Tibet to relive his the Islamic Tradition. Even though sneaking cameras and camcorders into Tibet is a risky business, the producers successfully created a small documentary on the subject which is not too well-known to most academics.

The last presentation on this panel was by Ahmad Tariq Karim of University of Maryland. This talk did not match the quality of the first two presentations. Mr. Karim, spoke on "Iran's Relations with China, IndiaPakistan \& Central Asia". The talk was poorly organized and not analytical enough to be taken seriously. Mr. Karim's central thesis from a number of ideas lumped together was that in light of new relationship between India and the US, main actors in South Asia were, India-US on one hand, and the Iran-India-China axis on the other! By implication, Pakistan was completely out of the scene. A rigorous comparative analysis was not made while comparing Iran's relations with India and Pakistan. Iran-India relationship was blown out of proportion while nothing positive was said of Iran-Pakistan relations. Reality as a matter of fact is different, because Iran's relations with Pakistan (despite the Taliban friction) are vibrant and have been ever cordial. The data on India-Iran relations was not new in the 
presentation, and the analysis was skewed because in any paper on foreign policy analysis, one expects all the major actors in the region and look at their decision making process as a result of domestic tension of those societies and their interaction at the systemic level. The paper lacked rigor thoroughly. It was learned that Mr. Karim has now become the new Bangladeshi ambassador to the US, which gives some explanation of what was being said. The third panel was on the Contemporary developments on Pakistan. Tamara Sonn of The College of William and Mary gave an excellent presentation on Post-Islamism in Pakistan in which she analyzed the new Islamic and cultural trends in the new generation of Pakistanis.

The same evening, keynote address was given by Dr. Akbar S. Ahmed. Dr. Ahmed, who has authored various books on Islam and produced the TV series and the film Jinnah. Dr. Ahmed who has been recently appointed as the Ibn Khaldun Chair of Islamic Studies at American University's School of International Service has written numerous works on the predicament of Islam in the Modern world. His keynote address "Islam and the End of Time: Living Dangerously in the 21st Century" was a message which narrated a similar theme and notably the same title on which he is working with Cambridge for Polity Press.

The talk opened with the metaphysics of being from the famous verse of Ghalib, the Muslim poet during the time of later Mughal Era of India. Dr. Ahmed ventured into the philosophical subject of time. He argued how historical thinking, which is a product of time, must not be confused with the transcendental ideals, which are ahistorical. Dr. Ahmed said: "I will argue that certain processes have been set in motion on a global scale, which have created conditions for the clear emergence of the signs, which indicate the end of time. I will point out the strong correlation between these signs, as we see them around us, and those that we read about in the holy texts. I will suggest that social behavior - particularly extreme aberrant behavior -is influenced by these signs, their frequency, scale and universal application."

The keynote address was an interesting demonstration of religious eschatology and its link with sociological and political behavior. According to Dr. Ahmed, The impact of globalization is universally causing major shifts in the way people think and behave across the world. To complicate matters further certain world civilizations seem to be on a collision course. Hindu savants believe that the world is entering the period of Kali Yoga or the Dark Age. Kali Yoga will see the clash between the forces of evil and 
good and the triumph of the latter. Many scholars and writers believe that while Hindus represent good, Muslims are the personification of evil. They want an all-out, once and for all, battle. This is a mirror image of how many Muslims feel in South Asia. It feeds into the call for jihad of groups like the Harkat-ul-Mujahideen. With both India and Pakistan now nuclear this cosmic confrontation takes on a new and sharpened urgency.

He said: "Just as the mood of uncertainty and risk has spread in parts of the Muslim and Hindu world, it has appeared in the Western world. It is a period in time when the two moods - which encourage certain behavior patterns and attitudes - reflect each other. The writers, intellectuals, filmmakers and poet's talk about the end of time in the West. The big blockbuster films of Hollywood predict the end of time as imminent whether in Blade Runner or The Terminator - and sales indicate a resonance in society. This apocalyptic mood creates a widespread sense of uncertainty. It is Armageddon. (Social scientists have labeled the societies of our time as "risk society"). The uncertainty of one civilization meets the uncertainty of another. It is not an easy time to have a relationship based on trust, compassion and balance between civilizations."

Finally, from within the Islamic eschatological viewpoint, Dr. Ahmed enumerated the signs of the end of time and correlated those to the observable phenomena. Despite the signs of end of time which seems imminent, he concluded for a call to understanding between peoples "If human beings" he said, "can generate ihsan, 'adl and 'ilm, [they can] restore balance in human society - and therefore how it treats nature and the environment - it would seem there would be hope."

The next day of the conference had two panels and an additional panel sponsored by the Project MAPS (Muslims and Public Square) from Georgetown University. On the panel on "Islam and Media", most notable of all the presentations was that of Dr. Ghulam Nabi Fai from the Kashmiri American Council. Dr. Fai in his "Kashmir: From Freedom Fighters to Fundamentalist Mercenary Terrorists", discredited India's timeworn arguments that the 53-year-old conflict in the territory listed as disputed by the United Nations Security Council is either a separatist or secessionist struggle; fueled by terrorism or foreign intermeddling; is a manifestation of Muslim fundamentalism; is too enigmatic for solution; is too old to be resolved by self-determination as prescribed by resolutions of the United Nations Security Council, that India itself accepted at the time as the fairest method conceivable for bringing peace and justice to that convulsed land. 
He gave evidence of how all the faiths practiced in Kashmir are part of the resistance to India's illegal 700,000 manned military occupation; Hindus, Muslims, Sikhs, and Buddhists. He further explained that a right of self-determination - whether for the Irish, the Namibians, citizens of the Baltic States, or Kashmir - never lapses because of time. Otherwise, the most villainous tyrannies would be rewarded by arch-villainy against the conquered and oppressed.

India is creating the impression as if the Security Council resolutions are out of date and the Simla Agreement has superseded these resolutions. This implication is false, because it would run counter to a standing principle of international relations which is set out in Article 103 of the Charter of the United Nations (accepted by every Member of the United Nations, including India), which says: "In the event of a conflict between the obligations of the Members of the United Nations under the present Charter and their obligations under any other international agreement, their obligations under the present Charter shall prevail"

The Simla Agreement expressly says that the relations between the two countries shall be governed by the principles and purposes of the Charter of the United Nations. One of the basic principles of the Charter (Article 33) is to seek a solution of any dispute by negotiation, enquiry, conciliation, arbitration, judicial settlement, resort to regional agencies or arrangements or other peaceful means. The linked principle (Article 34) is that the Security Council may investigate any dispute and (Article 36) at any stage recommend appropriate procedures or methods of adjustment.

$\mathrm{He}$ additionally noted the urgency of finding a peaceful solution in Kashmir because of the nuclear and missile arsenals of India and Pakistan, and because daily non-combatant Kashmiris are suffering hideous human rights violations - including extra-judicial assassinations, torture, and rape - that make the Slobodan Milosevic's atrocities against Kosovar Albanians seem gentle in comparison. He summoned India to negotiate with the genuine political voice of the 13 million people of Kashmir-the All-Parties Hurriyet Conference-to reach an accord that would command the approval of the Kashmiri people. If that is not done, India will discover that Kashmir will be its Vietnam, and everyone will be the loser.

Last but not the least, the project MAPS closing panel gave this conference a nice finish. Dr. Sulayman Nyang's presentation on "Pluralism and Muslim Political Participation in the USA" discussed some very important contingencies for the American Muslims. The United States of America has a unique position in the world today because it is home to 
all three monotheistic faiths of the Abrahamic tradition: Judaism, Christianity and Islam. The Project MAPS, which is based at the Center for Muslim-Christian Understanding (CMCU), Georgetown University, aims to promote a better understanding between these religious traditions. The center was founded in 1993 to foster a civilizational dialogue between the Muslim World and the West, Islam and Christianity. As part of the university's famous Edmund A. Walsh School of Foreign Service, it attracts students, visiting professors and noted scholars from Middle East, Asia, Europe and America. This intemational mix generates a cross-cultural view of the world and furthers the center's mission of dispelling discrimination and prejudice.

Smaller conferences such as this one are often interesting and more intense compared to the very large conferences, where due to quantity and diversity of presentations, one can only benefit from them partially. The 18th Annual Conference of ACSIS was hosted very well and we look forward to attending more of these discussions.

Ejaz Akram Managing Editor. AJISS 